\title{
Organisational Learning, Supportive Innovation Systems and Implications for Policy Formulation
}

\author{
Arne Isaksen • James Karlsen
}

Received: 29 September 2011 / Accepted: 30 September 2011 /

Published online: 11 October 2011

(C) Springer Science+Business Media, LLC 2011

This special issue is based on papers presented at the fifth International Seminar on Regional Innovation Policies at the University of Agder, Norway, October 14-15, 2010. The selection of papers in this issue covers three main themes at the seminar, namely work organisations and innovation, regional innovation systems and regional governance and policies. These themes, as the papers in this special issue, are interrelated. They are interrelated in the sense that how firms organise their learning and innovation activities affects the mode of innovation and, consequently, the type of supporting systems and policy tools that are most relevant. The idea is that firms that organise their innovation processes differently, for example by utilising diverse types of knowledge, need to bring in different types of supplementary competence and other resources from the innovation system, which then leads to the fact that specific policy tools are appropriate for specific types of firms. The understanding of the importance of differentiated or fine-tuned policy based on the specific knowledge bases and innovation modes of firms and sectors is a central topic in many articles in this issue. This guest editorial discusses main contents of the three mentioned themes of firms' innovation modes, supporting innovation systems and innovation policy. We focus on the relatedness of these themes and the contributions of the seven papers in advancing the understanding of the themes. We conclude by pointing to one upcoming research themes with regard to regional innovation policy.

\section{Work Organisation and Innovation Modes}

Innovation mode has become a key concept in innovation studies, economic geography and related subjects in order to underline the differentiated nature of

\footnotetext{
A. Isaksen $(\bowtie) \cdot J$. Karlsen

Department of Working Life and Innovation, University of Agder, Box 509, 4898 Grimstad, Norway e-mail: arne.isaksen@uia.no
}

\author{
A. Isaksen $\cdot$ J. Karlsen \\ Agder Research, Gimlemoen 19, 4630 Kristiansand, Norway
}


firms' learning and innovation processes $[1,15,17,26]$. Innovation modes denote main ways for firms to organise and carry out innovation and learning processes. The concept focuses in particular on the key, necessary competence for firms' innovation activities and how this competence is being created.

We distinguish between three main innovation modes. Firms often combine several innovation modes as firms, for example use different types of knowledge in specific phases of their product development activities [25]. Even so, most firms may be characterised by one dominant innovation mode. We should however keep in mind that innovation modes are theoretical categories that highlight typical ways of carrying out learning and innovation processes in firms, which are not always found in these pure forms in real firms. The three innovation modes are, however, useful analytical concepts in studies of firms' innovation activities.

A first innovation mode is the science-based Science, Technology, Innovation (STI) mode. Innovations, and first of all new products, are developed through research and development. STI firms have dedicated R\&D units, or include small, research intensive spin-off firms from, for example, universities. The firms are typically engaged in product and technology fields where research activities are necessary to be competitive.

The STI mode summarises in many ways the traditional idea of how innovation occur through a linear model [11]. The model conceptualises the innovation process as departing from ideas originating from firms' $R \& D$ activities and then going through stages of development, construction of prototypes, testing, industrialisation, production and marketing. It is characterised by technology push, and represents largely an elitist model in which innovation activities are reserved for the sciencebased and research-intensive firms. The Doing, Using, Interacting (DUI) mode was developed to counterbalance the STI model, exactly to demonstrate that there are other ways to be innovative than the science-based one. The DUI model is also seen to illustrate how innovation activities occur in the larger part of small- and mediumsized firms.

The DUI mode is seen as essential in industries where firms do not build their innovation activities mainly on research-based knowledge, but rather on competence acquired through experience-based learning from working long time with specific activities. These firms create new solutions in their 'daily work' in order to solve practical problems in their own production or to adapt solutions to specific requests by customers. Solutions are mainly found through trial and error, through building on existing knowledge and experiences, but without necessarily knowing how new solutions do function.

To really be efficient, the DUI mode requires learning organisations, characterised by decentralised responsibility, team work, employees' circulation between tasks and firms' investment in employee training [18]. Such organisations in many ways resemble what Gustavsen (in this issue) denotes as 'good work' which is a specific characteristic of Nordic work life. Leaning organisations stimulate on-the-job learning, and helps employees at many levels to solve upcoming problems and to propose improvements in products, services and production processes ([6]: 369). Lorenz (in this issue) demonstrates that learning organisations are particularly innovative. 
The DUI mode nevertheless has some problems with regard to more radical innovation activities. The DUI mode typically consists of customer-driven innovation in which customers' request are often solved ad hoc by the use of much tacit, experience-based competence. Firms then risk starting almost from scratch in every new customer project, if the firms' core knowledge remains tacit and less systematic. Several studies point to the fact that firms combining the DUI and the STI innovation mode are generally more innovative than firms focusing on one of the modes. Jensen et al. ([17], p. 685) thus concluded that 'firm that combines a strong version of the STI mode with a strong version of the DUI mode (...)' excels in product innovation, while Laursen and Salter ([19], p. 131) find that 'firms (...) who search widely and deeply tend to be more innovative'.

Isaksen and Karlsen [15] have conceptualised and described a third innovation mode, denoted as Complex and Combined Innovation (CCI) that exactly combines elements from the two other modes. This occurs, for example, through the development and/or absorption of science-based knowledge and then its diffusion, transformation and/or redevelopment by a wide range of workers and managers in organisations [26]. A key aspect of the CCI mode regards responding to a weak part of the DUI mode as CCI firms systematise their core competence by the development of technology platforms.

The CCI innovation mode can be illustrated by an example from the firm Kongsberg Automotive (KA), located at Raufoss in south-east Norway. KA produces some tens of millions of couplings for brakes in trucks each year [15]. The firm has over the last 10 years or so changed its technological platform from brass to composite. As typical in the CCI mode, the development of a new type of couplings made in composite has involved the linking of many types of competence, both at new employees in KA with competence in composite and experienced production workers with regard to developing the production process. KA also used the competence at $R \& D$ institutes in material technology, a specialised firm and a machine-building company, and Volvo as a pilot customer. This process then links customer-driven innovation and technology push in the development of composite as a new technological platform in KA.

The CCI mode is characterised by system integration which denotes the linking of specialised, explicit and tacit knowledge across functional boundaries [23]. The integration of different types of knowledge and skill is complicated as it requires several types of specialised competence in firms, not least that firms are able to put scientific knowledge to practical use. The complexity of system integration is illustrated by the fact that it is often difficult to achieve outside particular industrial districts ([5], p. 102) owing to the importance of gained experience and tacit knowledge which make geographical proximity critical in knowledge exchange. Malecki [23] thus maintains that multinational corporations largely keep system integration activities at their home base. System integration is typically not moved to new locations in China and India, and is at all difficult to achieve in China and India because these countries (for the time being) have few advanced manufacturing milieus. Thus, Malecki [23] concludes that China and India do not represent any real threat to western countries when it comes to advanced innovation activities building on system integration. These ideas are to a large extent supported by the analyses in the articles of Gustavsen and Lorenz in this issue which point to the relative 
importance of 'good work' and learning organisations in the high-performing Nordic countries. These countries may have some advantages when it comes to the linking of different types of competence, due to a generally well-educated labour force, flat organisations and to some extent effective cooperation between academia and industry, amongst others.

\section{Supporting Regional Innovation Systems}

A next topic regards what support the individual innovation mode requires, and particularly how one may stimulate the development of the CCI mode. If the CCI mode, as we indicate, contributes to more innovative as well as more locally embedded firms, a strategically important task should be to support the development of this mode, for example by helping DUI firms to move in that direction.

The development of the CCI mode requires organisational changes, such as systematising of firms' core competence. We will however focus on key assets in the external environment that can support the different innovation modes. This is seen as a relevant approach as innovating firms have to get hold of different external resources as 'a central finding in innovation research is that firms seldom innovate in isolation' ([12], p. 180). Innovative firms basically supplement their unique, internal competence by external, specialist competence from a number of different actors. This open innovation approach [7] is not least important as a result of the increasing knowledge content and complexity of many products.

The concept of regional innovation system constitutes one framework in order to analyse how external environments can support firms' diverse innovation activities. We underline that regional innovation system is an analytical framework or what Lundvall ([20], p. 98) denotes as a focusing device. The model of regional innovation system is no blueprint for how to create a more innovative regional industry, rather a conceptual construct to study important aspects of innovation and learning processes.

A regional innovation system (RIS) consists briefly speaking of two subsystems ([10], pp. 104-105). Firstly, the firms in a region, that may form one of several clusters, and secondly, the knowledge infrastructure of research, education and diffusion organisations. The RIS framework further emphasises that knowledge flow between actors in the two subsystems support innovation processes, and knowledge flow is stimulated, for example, if universities have study programmes and research areas of relevance to the needs of a region's industry. The knowledge flow is facilitated by informal institutions that improve collaboration and coordinate joint activities among actors, and also supported by policy instruments [3]. It is also important to keep in mind that regional innovation systems are open in the sense that relevant knowledge and innovation partners can be found both in the region and outside of the regions in question, for example when firms are linked to global supply chains and knowledge networks [4].

The argument here is that firms and industries with different dominant innovation modes need different types of support from the regional innovation system. The STI innovation mode is based on the use of scientific knowledge (Table 1), which is 
largely explicit, and thus, in principle, can be acquired anywhere as long as firms hold necessary absorptive capacities. STI firms can therefore engage in innovation collaboration with researchers, firms and research laboratories over long geographical distances, as seen in studies of the biotechnological industry [25]. Knowledge flows in this industry occurs in global networks [13]. But STI firms may still benefit from geographical proximity to some partners, and in particular to research milieus where brand new knowledge is developed early on. Firms may then be able to utilise the new knowledge before it becomes widely available through, amongst others, scientific journals, and firms are often more able to recruit nearby persons that have taken part in the development of new research-based knowledge [9]. Local researchbased knowledge must, however, be of 'world class' to be relevant for STI firms, as firms may access the knowledge from many places.

STI firms, first of all, need support from a narrow innovation system, which focuses on research organisations and education institutions that develop and diffuse scientific knowledge [20]. DUI firms, on the other hand, often require little support from actors in the knowledge development and diffusion subsystem of the regional innovation system. DUI firms, first of all, use ideas and knowledge from customers and suppliers in their innovation activities, and can thus function in the case of thin RIS [27]. However, DUI firms benefit from specialised labour markets and the knowledge flow following the recruitment of new workers with related skills. Even though firms can recruit specialists anywhere, labour markets have still largely a regional extent (cf. [24], pp. 154-155). This is not least the fact with regard to the skilled workers that perform much of the incremental and bottom-up innovation activities in DUI firms, who hold much context-dependent competence which is often not particularly useful outside the firm and the region where the knowledge has been acquired. This implies that regional education institutions with study programmes adapted to dominant regional industries are of key importance for DUI firms.

The CCI innovation mode builds on firms' system integration capabilities, i.e. the capabilities of linking, adapting and employing both scientific and experience-based knowledge from several internal and external sources. This capability may be seen as more complex than that of STI and DUI firms. STI firms require scientific knowledge to carry out their mainly technology push innovation activities, while DUI firms need experience-based competence to, in particular, adapt existing solutions to the demand of individual customers. CCI firms also have to meet the

Table 1 Linking of innovation modes and regional innovation systems

\begin{tabular}{lll}
\hline Innovation mode & $\begin{array}{l}\text { Strategic resource for } \\
\text { innovation activities }\end{array}$ & $\begin{array}{l}\text { Characteristics of regional } \\
\text { innovation systems }\end{array}$ \\
\hline STI & Scientific knowledge & $\begin{array}{c}\text { Narrow RIS, but with national and } \\
\text { international R\&D links }\end{array}$ \\
CCI & Experience-based competence & $\begin{array}{c}\text { Thin RIS is possible, but benefit from } \\
\text { regional adapted education and training } \\
\text { Broad RIS, and particularly regional/ } \\
\text { national R\&D and education }\end{array}$ \\
\hline
\end{tabular}


needs of individual customers, but at the same time develop a technology platform as a basis for their individually adapted solutions.

CCI firms will benefit from a broad innovation system with actors holding different types of skills and knowledge [20]. A broad innovation system includes other actors than those that mainly support firms' research activities, not least secondary schools and higher education institutions. It includes also actors contributing to firms' access to and use of existing knowledge, such as consultants, other firms, incubators and technology centres. Regional innovation systems with a wide range of possible knowledge organisations and actors are not that common, particularly in peripheral and old industrial regions (as maintained by [27]). Research-based knowledge to be employed by CCI firms (and STI firms) is often so specialised that the regional research capabilities often cannot support the range of such knowledge, thus, Table 1 maintains that CCI firms also have to rely on knowledge from the national level, (and certainly in some cases also the international level).

Even the regional innovation systems of (some) metropolitan regions may have problems in supporting the range of competence needed by CCI firms. This is indicated, for example, by Isaksen and Onsager [14] who find that the four largest city regions in Norway jointly have a lower product and process innovation rate (measured as per cent firms with product and process innovation 2004-2006) than the average for Norway. These large city regions, however, have a higher patent rate than the national average, pointing to the fact that their innovation system may, in particular, stimulate innovation activities in STI firms. One possible explanation for the overall lower innovation performance in the four largest city regions relates then to the fact that their regional innovation systems may be geared towards supporting STI firms and industries. This may again partly reflect the fact that much traditional manufacturing industry and its competence base have disappeared from these city regions [14].

\section{Differentiated Regional Innovation Policy}

The understanding that innovation activities occur quite differently in diverse types of firms, which also have specific needs for supporting institutions, should have some implications for the design and carrying out of innovation policy. It implies that no best practice models that fit every situation exist, rather policy tools have to be adapted to firm and sector-specific characteristics. However, Martin, Moodysson and Zukauskaite (in this issue) find that policy support programmes targeting three very different industries in the region of Skania are very similar in scope in providing more or less generic support following some best practice models.

We here define innovation policy broadly as policy that explicitly aims to promote the development, diffusion and efficient use of new products, services and processes [21]. The traditional technology push policy approach inspired by the linear innovation model is particularly supportive of the STI innovation mode. The rational for this policy is found in the neoclassical economy concept of market failure [22]. The idea is that if markets are left to themselves, it will lead to underinvestment in science and technology due to externalities, i.e. that knowledge 
flows freely and costless between organisations. As innovations are seen as direct results of research, policy inspired by this idea should focus on supporting R\&D activities in firms and research institutions, but also strengthen higher education and knowledge exchange between knowledge organisations and industry, including to stimulate academic spin-offs (Table 2).

The second generation innovation policy [16] developed in the 1990s has a very different understanding than the technology push approach of how innovation activities take place. Innovation is conceptualised as interactive learning among many players, in which $\mathrm{R} \& \mathrm{D}$ organisations are only one possible type. The policy thus focuses on stimulating interaction and knowledge exchange between several different organisations. Systemic failures is then an important rational for this second-generation policy. The concept of systemic failures is inspired by evolutionary and institutional economics, especially the system-of-innovation school [22]. This school regards innovation processes as taking place in cooperation between various actors and supported by an institutional infrastructure of knowledge and diffusion organisations, rules of the game and so on. From this follows that innovation processes are hampered if the institutional infrastructure has severe deficiencies or does not function well. The failures can be classified as problems related to the components (such as the universities) of the innovation system, and those related the functioning of the system, for example barriers for efficient knowledge exchange between firms and universities [6]. Thus, policies should focus on aligning such systemic failures.

The second-generation policy with its focus on other triggering factors for innovation than new scientific knowledge is much more appropriate for the DUI type of firms than the technology push approach. The second-generation policy emphasises market signals and customer requirements as vital triggering factors. Policies to support the DUI innovation mode then involve enabling interactions between users and producers, for example by trust building and joint projects (Table 2). On the organisational level, stimulating organisational innovation that results in more learning organisations is vital, as 'the lack of learning organisations is a serious obstacle for the development of DUI forms of learning ([6]: 369). More indirect ways to stimulate DUI innovation is through active labour market policies,

Table 2 Types of policy tools at organisational level (number 1) and the innovation system level (number 2)

\begin{tabular}{|c|c|c|c|}
\hline \multirow{2}{*}{$\begin{array}{l}\text { Target of } \\
\text { support }\end{array}$} & \multicolumn{3}{|l|}{ Innovation mode supported } \\
\hline & $\begin{array}{l}\text { STI mode } \\
\text { (science driven) }\end{array}$ & $\begin{array}{l}\text { DUI mode } \\
\text { (demand driven) }\end{array}$ & $\begin{array}{l}\text { CCI mode } \\
\text { (system integration) }\end{array}$ \\
\hline \multirow{3}{*}{$\begin{array}{l}\text { Typical } \\
\text { type of } \\
\text { policy } \\
\text { tools }\end{array}$} & $\begin{array}{l}\text { 1. Support R\&D projects } \\
\text { in organisations }\end{array}$ & $\begin{array}{l}\text { 1. Support on-the-job learning and } \\
\text { organisational innovations }\end{array}$ & $\begin{array}{l}\text { 1. Support capability } \\
\text { building in organisations }\end{array}$ \\
\hline & $\begin{array}{l}\text { 2a. Support joint R\&D } \\
\text { projects between firms } \\
\text { and universities }\end{array}$ & $\begin{array}{l}\text { 2. Stimulate trust building and } \\
\text { joint innovation projects } \\
\text { between producers and users }\end{array}$ & $\begin{array}{l}\text { 2. Support innovation } \\
\text { cooperation with a broad } \\
\text { spectre of external actors }\end{array}$ \\
\hline & $\begin{array}{l}\text { 2b. Support higher } \\
\text { education programmes }\end{array}$ & & \\
\hline
\end{tabular}


and policies aiming at broad-based education systems and life-long learning ([6] and Lorenz in this issue).

Policies to support CCI activities should, in principle, link the science-driven approach of most relevance for STI firms and the user-driven approach of particular relevance for DUI firms. The policy can then be appropriate for organisations beyond the research-intensive ones, and it can support the building of technology platforms in typical DUI firms beyond the focus of the user-driven innovation processes. The last point pertains to the fact that DUI firms typically carry out incremental changes in ordinary projects or in their daily activities. It is difficult in such cases to employ the knowledge of external researchers when the innovation activity is part of other activities in firms and difficult to separate. Typical DUI firms have to systematise their core knowledge, develop R\&D units or at least distinguish specific innovation projects for these firms to be able to cooperate with external experts. The firms need to increase their internal research competence and capacity to introduce more STI-based innovation activities. This first of all demands recruiting higher educated personnel, which again requires relevant study programmes and $\mathrm{PhD}$ education at, first of all, regional universities. Own research activities is also required for firms to enter into cooperation with external R\&D institutes [8].

Typical STI firms, on the other hand, can have problems to commercialise research results due to a lack of knowledge in setting up production lines, in organising logistics, marketing, etc. This relates to a more general question of how STI firms can draw more on customers and actors in the broad innovation system, and also make more use of experience-based knowledge from different parts of the firms, in innovation projects.

A common theme in contributing to make DUI firms more research-based and STI firms more able to employ experience-based knowledge is capability building. This includes building more research competence within DUI firms and building more competence in industrialisation and commercialisation in (some) STI firms. DUI firms must be able to use the expertise in research institutes, regardless of their location. STI firms need to cooperate with applied R\&D institutes, consulting firms, etc. in parts of their innovation projects, which is often most easily achieved in situations of geographical proximity [2]. Implicit in this argument is that 'CCI policy' should make it more possible for original DUI and STI firms to utilise both the narrow and the broad regional innovation system. Policies of linking science and user-driven innovation activities should then focus on the building of capabilities in firms and R\&D organisations, and on supporting cooperation with a broad spectre of external actors (Table 2).

\section{Policy Formulation and Implementation}

This special issue covers the three themes discussed above. The articles by Gustavsen and Lorenz concentrate on work organisations and innovation. Gustavsen discusses how learning oriented forms of work organisation have historically developed in the Nordic countries, while Lorenz, building on an extensive statistical material, demonstrates a positive relation between the development of creative forms 
of learning and regional innovative performance. The creative forms of learning as defined by Lorenz are particularly extensive in Norway and Sweden. The three articles by Herstad, Pålshaugen and Ebersberger, Tödtling, Schneider, Grillitsch and Höglinger, and Martin, Moodysson and Zukauskaite link the two other themes of this special issue, namely types of innovation activities of regional industries and policy support tools. Herstad, Pålshaugen and Ebersberger depart from studies of the firms' innovation collaboration in the Oslo region and draw some policy lessons. The two other mentioned articles depart more from the policy side in analysing to what extent specific policy programmes are adapted to regional circumstances.

The two articles by Aranguren and Larrea, and Gausdal and Nilsen take another and very welcomed approach to analysing policy tools. These articles centre on how specific policy tools have been implemented and made helpful for their target group of users. This approach points to the fact that policy instruments are not automatically taken up by potential users; instruments need to recruit users, to be adapted to different groups of users, must be organised and managed effectively, etc. This may, in particular, be the case with regard to 'soft instruments', for example cluster projects, which may include raising the local commitment and collaboration among diverse cluster participants. We see a need for more linking of the two approaches that deal with how to select the most appropriate policy strategy in specific regional situations, and how to implement and adapt the strategies successfully.

\section{References}

1. Arundel A, Lorenz E, Lundvall B-Å, Valeyre A (2007) How Europe's economies learn: a comparison of work organization and innovation mode for the EU-15. Ind Corp Change 16(6):1175-1210

2. Asheim BT (2011) Innovation and the role of diversity in the globalising knowledge economy. Forthcoming in: Johnsen HCG, Ennals R (eds) Creating collaborative advantage: Innovation and Knowledge Creation in Small Open Economies. Gower, Surrey

3. Asheim BT, Gertler M (2005) The geography of innovation: regional innovation systems. In: Fagerberg J, Mowery D, Nelson R (eds) The Oxford handbook of innovation. Oxford University Press, Oxford, pp 291-317

4. Asheim BT, Isaksen A (2002) Regional innovation systems: the integration of local 'sticky' and global 'ubiquitous' knowledge. J Tech Tran 27:77-86

5. Best MH (2001) The new competitive advantage. The renewal of American industry. Oxford University Press, Oxford

6. Charminade C, Lundvall B-Å, Vang J, Joseph J (2009) Designing innovation policies for development: towards a systemic experimentation-based approach. In: Lundvall B- $\AA$, Chaminade C, Joseph KJ, Vang J (eds) Handbook of innovation systems and developing countries. Building domestic capabilities in a global setting. Edward Elgar, Cheltenham, pp 360-379

7. Chesbrough HW (2003) The era of open innovation. MIT Sloan Management Rewiew, Spring:35-41

8. Cohen WM, Levinthal DA (1990) Absorptive capacity: a new perspective on learning and Innovation. Adm Sci Q 35:128-152

9. Cooke P (2002) Knowledge economies. Clusters, learning and cooperative advantage. Routledge, London

10. Cooke P, Boekholt P, Tödtling F (2000) The governance of innovation in Europe. Regional perspectives on global competitiveness. Pinter, London

11. Fagerberg J (2005) Innovation. A guide to the literature. In: Fagerberg J, Mowery DC, Nelson RR (eds) The Oxford handbook of innovation. Oxford University Press, Oxford, pp 1-26

12. Fagerberg J, Mowery DC, Nelson RR (eds) (2005) The Oxford handbook of innovation. Oxford University Press, Oxford 
13. Gertler MS, Levitte YM (2005) Local nodes in global networks: the geography of knowledge flows in biotechnology innovation. Ind Innovat 12(4):487-507

14. Isaksen A, Onsager K (2010) Regions, networks and innovative performance. The case of knowledgeintensive industries in Norway. Eur Urban Reg Stud 17(3):227-243

15. Isaksen A, Karlsen J (2011) Combined and complex mode of innovation in regional cluster development - analysis of the light-weight material cluster in Raufoss. Forthcoming in: Asheim B, Parilli MD (eds) Interactive learning for innovation: a key driver within clusters and innovation systems. Palgrave-Macmillan, Basingstoke

16. Jakobsen S-E, Onsager K (2008) Innovasjonspolitikk for regional næringsutvikling. In: Isaksen A, Karlsen A, Sæther B (eds) Innovasjoner i norske næringer - et geografisk perspektiv. Bergen, Fagbokforlaget, pp 269-288

17. Jensen MB, Johnson B, Lorenz E, Lundvall BÅ (2007) Forms of knowledge and modes of innovation. Res Policy 36:680-693

18. Lam, A, Lundvall B- $\AA$ (2006) The learning organization and national systems of competence building and innovation. In: Lorenz, E, Lundvall, B-Å (eds) How Europe's economies learn: coordinatring competing models. Oxford University Press, Oxford, pp109-139

19. Laursen K, Salter A (2006) Open for innovation: the role of openness in explaining innovation performance among U.K. manufacturing firms. Strateg Manag J 27:131-150

20. Lundvall B-Å (2007) National innovation systems - analytical concept and development tool. Ind Innovat 14(1):95-119

21. Lundvall B-Å, Borrás S (1997) The globalising learning economy: implications for innovation policy. Report from DG XII, Commission of the European Union

22. Niosi J (2010) Building national and regional innovation systems. Institutions for economic development. Edward Elgar, Cheltenham

23. Malecki EJ (2010) Global knowledge and creativity: new challenges for firms and regions. Reg Stud 44(8):1033-1052

24. Malmberg A (2003) Beyond the cluster-local milieus and global connections. In: Peck J, Yeung HW (eds) Remaking the global economy. Economic-geographical perspectives. Sage, London, pp 145-159

25. Moodysson J (2008) Principles and practices of knowledge creation: on the organisation of "buzz" and "pipelines" in life science communities. Econ Geogr 84(4):449-469

26. Parille MD, Elola A (2011) The strength of science and technology drivers for SME innovation. Published online in Small Business Economics

27. Tödtling F, Trippl M (2005) One size fits all? Towards a differentiated regional innovation policy approach. Res Policy 34(8):1203-1219 